\title{
Turizm ve Rekreasyonel Tercihlerin Demografik Yapıya Göre Değişiminin Tekirdağ Örneğinde İncelenmesi
}

\author{
Elif Ebru ȘISSMAN ${ }^{1}$, Murat ÖZYAVUZ ${ }^{1}$, Pınar GÜLTÜRK ${ }^{1 *}$ \\ ${ }^{1}$ Tekirdağ Namık Kemal Üniversitesi, Güzel Sanatlar, Tasarım ve Mimarlık Fakültesi, Peyzaj Mimarlı̆̆ı Bölümü, \\ 59030, TEKİRDAĞ
}

\section{Öz}

Günümüzde turizm ve rekreasyonel aktivitelere olan talep sürekli artmaktadır. Bu aktivitelerin sağlıklı bir şekilde gerçekleştirilebilmesi için faaliyetlere olan talebin, bireylere göre farklılıklar gösterse de belirlenmesi önem taşımaktadır.

$\mathrm{Bu}$ araştırma, halkın demografik yapısının rekreasyonel tercihlere etkisinin araştırılması ve kent halkının rekreasyonel eğilim ve taleplerinin belirlenmesi amacıyla yürütülmüştür. Bu amaç doğrultusunda Tekirdağ il genelinde yürütülen çalışmada 11 ilçede toplam 543 kullanıcı ile anket yapılmıştır. Ankette demografik özelliklerden cinsiyet, yaş, eğitim ve gelir durumu ele alınarak sonuçlar istatistiki olarak analiz edilmiştir. Analiz sonucunda demografik yapının; bireylerin turizm ve rekreasyonel tercihlerinin neler olduğunun belirlenmesine, tercih etme sebeplerine ve aktivite sıklığına etkisinin olduğu tespit edilmiştir. Özellikle kullanıcıların eğitim durumunun bütün aktivitelerde etken olduğu görülmüştür. Bu sonuçlar yerel ölçekte yapılan benzer çalışmalarla paralellik göstermektedir.

Anahtar Kelimeler: Rekreasyon, turizm, demografik yapı, peyzaj.

\section{Investigation of Tourism and Recreational Preferences by Demographic Structure in Tekirdag Case Study}

\begin{abstract}
Demand for tourism and recreational activities is constantly increasing and it varies from person to person as individuals represent different demographic background. Therefore, it is important to consider demographic structure to determine the demand.

This study was carried out to identify the effect of demographic structure on the recreational preferences and tendencies, and demands of the urban population. A survey was conducted with a total of 543 users in 11 districts of Tekirdağ province. Demographic characteristics were analyzed by gender, age, education and income. Statistical analysis showed that demographic structure influences to determine what the tourism and recreational preferences, the reasons of their chosen and frequency of activities. Particularly the educational background is a main determinant of recreational and tourism preferences. These results show parallelism with the similar studies conducted on local scale.
\end{abstract}

Keywords: Recreation, tourism, demographic structure, landscape. 


\section{Giriş}

Kentlerin plansız büyümesi ve bununla birlikte artan sanayileşme faaliyetleri gibi nedenlerle kent insanı; doğal olmayan, gürültülü, kendi üzerlerinde baskı yaratan çevrelerde yaşamak zorunda kalmaktadır. İnsanların bu ortamdan uzaklaşıp serbest zamanlarını değerlendirmek için kentiçi ve yakın çevresindeki rekreasyonel alanlara olan talepleri her geçen gün artmaktadır.

Günümüzdeki anlamıyla rekreasyon ve turizm olguları, serbest zamanların değerlendirilmesi amacına yönelik olarak oluşmaya başlamışıı (Çabuk, 1996).Rekreasyon ile turizm arasında bir iliş̧ki mevcuttur. Her rekreasyonel faaliyet turizm değildir, ancak turizmin her çeşidinde rekreasyon vardır (Erdoğan, 1996). Topuzlu (1989) turizm ve rekreasyon arasındaki ilişkilerin ana kaynağının her ikisinin de serbest zamanda yapılması olduğunu ifade etmektedir (Kolcu, 1993). Çalıkoğlu (1989)'na göre turizm ve rekreasyon kaynakta birleşen, amaçta ayrılan iki değişik hareket biçimidir (Kolcu, 1993). Her iki olgu da her yaştaki ve sosyal yapıdaki bireyler tarafindan, serbest zamanlarda gönüllü olarak yapılır (Örücü, 2002).

Çevreyi geliştirmek, ulusal mirası korumak ve restore etmek için harcanan çabalar, rekreasyon ve turizme katkıda bulunur. Bu şekilde çevresel değerlerin kalitesi yükseldikçe, kaynak değeri de artmakta ve turizm de olumlu yönde gelişmektedir (Karaküçük, 1999; Sarı, 2001; Örücü, 2002). Öte yandan, turizm ve rekreasyonel faaliyetlerin varlık nedeni olan çevre, aynı zamanda turizm ve rekreasyonel faaliyetlerden dolayı bozulup yok edilebilir (Oğuz, 1991). İyi yönetilmeyen ve yönlendirilmeyen turizm ve rekreasyon hareketleri doğal çevre tahribi; görsel kalitenin bozulması, hava, su, toprak ve gürültü kirliliği, turistik mal ve hizmet üretim ve tüketiminden geriye kalan zararlı atıkların doğayı ve sosyal yaşamı kirleterek insan sağlığını tehlikeye sokması gibi sorunlara neden olabilir (Oğuz, 1991; Örücü, 2002). Doğal çevrede yaşanabilecek bu gibi olumsuz gelişmeler, bireylerin turizm ve rekreasyonel eğiliminin belirlenmesinde rol alır.

Rekreasyonel eğilim ve talepleri etkileyen unsurlardan bir diğeri de kullanıcıların demografik yapılarına bağlı değişkenlerdir. Talay ve ark. (2010)'larına göre kullanıcıların tutumları, algılama ve tercihlerini etkileyen faktörlerin neler olduğunun bilinmesi rekreasyon kalitesinin sağlanması açısından önemli bir koşuldur. Sosyodemografik faktörler; yaş, cinsiyet, eğitim düzeyi, medeni durumu, ekonomik düzey ve meslek grubu olarak alt faktörlere ayrılır (Davras Manap, 2016). Rekreasyonel faaliyet alanlarını planlanması ve tasarlanması aşamasında kullanıcılarının özellikleri ve isteklerinin bilinmesi, yapılacak çalışmaların kullanılabilir ve uzun vadeli olması sonucunu doğurmaktadır (Sağlık ve Kelkit, 2014).

$\mathrm{Bu}$ çalışma, turizm ve rekreasyonel faaliyetler ile demografik yapı arasındaki ilişkiyi incelemek amacıyla Tekirdağ ilinde yürütülmüştür. $\mathrm{Bu}$ amaç doğrultusunda kullanıcıların turizm ve rekreasyona ilişkin yaklaşımlarının ortaya konulması ve bu alanlarda gelecekte planlanacak faaliyetlerin ne şekilde ve hangi niteliklere sahip olması yönünde yol gösterici olması hedeflenmektedir.

\section{Materyal ve Metot}

Araştırma konusu olarak seçilen Tekirdağ ili Marmara Bölgesinin Trakya yakasında bulunur; doğuda İstanbul, güneyde Marmara Denizi ve Çanakkale, batıda Edirne, kuzeyde Kırklareli ve kuzeydoğuda Karadeniz ile çevrilidir (Şekil 1). 2012 yllında büyükşehir statüsü kazanan il 11 ilçeye sahiptir.

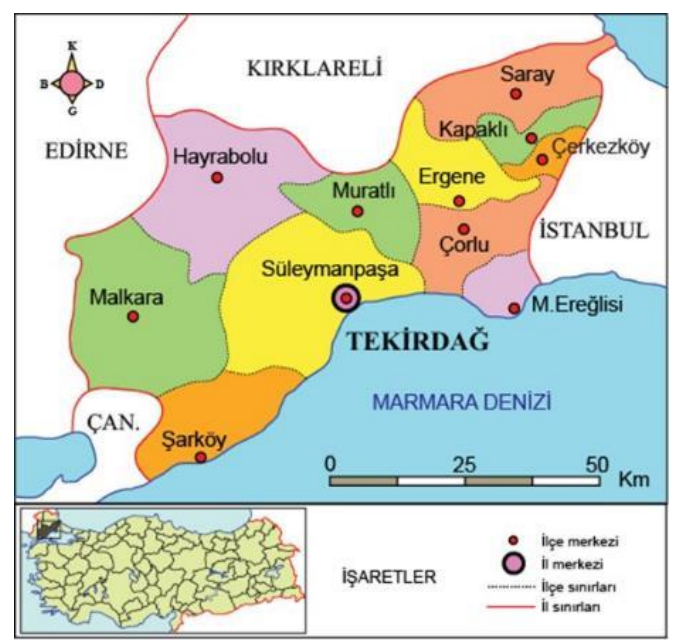

Şekil 1. Çalışma alanı ve konumu 
Araştırma 3 aşamada gerçekleştirilmiştir.

- İlk aşamada; il genelinde turizm ve rekreasyon aktivitelerini belirlemek için ön etüt çalışması ve literatür taraması yapılmış, çalışma alanının mevcut durumunu ortaya koymak için doğal, tarihi ve kültürel kaynakların envanteri çıkarılmıştır. Ayrıca kullanıcıların ve halkın rekreasyonel eğilimlerini ortaya koymak amaçlı standart anket formları hazırlanmıştır.

- İkinci aşamada anket çalışması gerçekleştirilmiştir. Hazırlanan standart anket formları araştırmacılar tarafından birebir karşıllkkl görüşme şeklinde doldurulmuştur.

- $\quad$ Üçüncü ve son aşama ise değerlendirme ve sonuç aşamasıdır. Anket çalışması istatistiki olarak analiz edilmiş ve yorumlanmıştır.

Çalışma kapsamında yapılan anket sayılarını belirlenmesinde aşağıdaki yöntem uygulanmıştır. Görüşülecek denek sayısının belirlenmesinde, oransal örnek hacmi formülü kullanılmıştır (Miran, 2002).

$$
n=\frac{N p(1-p)}{(N-1) \sigma_{\hat{p}_{x}}^{2}+p(1-p)}
$$

Yukarıdaki formülde; $\mathrm{n}=$ Örnek hacmi; $\mathrm{N}=$ Araştırma kapsamına giren bölgedeki nüfus sayısı = Varyans; araştırmada maksimum örnek hacmine ulaşılmak istenmesinden dolayı örnek büyüklüğünün mümkün olduğu kadar büyük olmasını sağlayan, $p(1-p)$ çarpımında en büyük değeri verecek olan $p=0.50$ değeri kabul edilmiştir.

$\mathrm{N}$ değeri için, tüm kent halkının eğilim ve taleplerini yansıtması amacıyla kenti oluşturan ilçelerin nüfusları dikkate alınıp, \%90 güven aralığı ve \%5 hata payı için örnek hacmi her bir ilçe için hesaplanmış, hesaplama sonucunda Tekirdağ Büyükşehir Belediyesi sınırları içerisinde yer alan 11 ilçede toplam 543 adet anket yapılmıştır (Tablo 1). Anketler Nisan, Mayıs ve Haziran aylarında rastgele seçilen denekler ile yüz yüze görüşme şeklinde gerçekleştirilmiştir. Anket verilerinin analizi için $\chi^{2}$ (Chi Square Test) testi ile gruplar arasındaki ilişkiler belirlenmiştir.

Tablo 1. İlçe nüfusları ve yapılan anket sayıları

\begin{tabular}{lll}
\hline İlçeler & Nüfus & Anket Sayısı \\
\hline Süleymanpaşa & 179.239 & 68 \\
Çorlu & 225.540 & 68 \\
Çerkezköy & 113.134 & 68 \\
Kapaklı & 85.898 & 68 \\
Ergene & 56.787 & 57 \\
Malkara & 53.293 & 53 \\
Saray & 47.171 & 47 \\
Hayrabolu & 33.839 & 34 \\
Şarköy & 29.994 & 30 \\
Muratlı & 26.764 & 27 \\
Marmara Ereğlisi & 22.816 & 23 \\
\hline TOPLAM & $\mathbf{8 7 4 . 4 7 5}$ & $\mathbf{5 4 3}$ \\
\hline
\end{tabular}

\section{Bulgular ve Tartışma}

Bireylerin yaş, cinsiyet, eğitim ve gelir durumu gibi bireysel ve sosyo-ekonomik özellikleri rekreasyon alanı seçiminde ve yapılan rekreasyon türünde oldukça etkilidir. Bu özellikler rekreasyon katılımını sınırlandırmakta ya da artırmakta, yönlendirmekte, zevklerin oluşmasını etkilemekte yani doğrudan ya da dolaylı olarak rekreasyonel alışkanlıklara etki etmektedir. Bu nedenle bireysel özelliklerin belirlenmesi önem taşımaktadır.

$\mathrm{Bu}$ çalışma kapsamında Tekirdağ il genelinde turizm ve rekreasyonel aktiviteler ile bireylerin demografik özellikleri arasındaki ilişkiler belirlenmiştir. Ankette4 tanesi sosyo-demografik olmak üzere toplam 13 soru sorulmuştur. Ankette katılımcılara; rekreasyonel turizm aktivitesi dendiğinde ilk aklınıza gelenler, Tekirdağ'da turizm ve rekreasyonel amaçlı yapılan aktiviteler, bu aktivitelerin tercih edilme/edilmeme nedeni ve sıklığı, mevcut turizm olanaklarının değerlendirilmesi, turizm ve rekreasyonel faaliyetleri kısıtlayan etmenler, turizme ve rekreasyonel faaliyetlere yönelik tesislerin hizmet kalitesi, turizmin tanıtılmasina yönelik hangi eylemlerin daha etkili olduğu, turizm ve rekreaasyonel faaliyetleri doğrudan ya da dolaylı olarak etkileyen çevre sorunlarının neler olduğuna ilişkin çeşitli sorular yöneltilmiş̧ir. Bu sorulardan istatistiki analize göre; aktivite çeşitliliği, katılım sıklığı, tercih etme nedenleri ve faaliyetleri etkileyen çevre sorunlarının neler olduğuna yönelik soruların sonuçları anlamlı bulunmuştur.

Araşıırmaya katılanların demografik özelliklerini belirlemek için anket formunda katılımcıların cinsiyet, yaş, 
eğitim düzeyi ve gelir durumuna ilişkin sorular sorulmuştur. İl genelinde demografik özellikler değerlendirildiğinde, katılımcıların \%46'sı erkek \%54'ü kadındır. Katılımcıların yaşları ise; \%16'sı 18-24, \%30'u 25-34, \%26's1 35-44, \%19'u 45-54 ve \%9'u ise 55 yaş ve üzeridir. Eğitim durumu incelendiğinde \%14'ü okuryazar, \%15'i ilköğretim, \%23'ü lise, \%7'si önlisans, \%31 lisans, \%9'u yüksek lisans, \% 1'i ise doktora mezunudur. Gelir durumu değerlendirildiğinde \%22'si asgari ücret (1300 TL [2016 Y111]), \%30'u 10001999 TL, \%28'i 2000-2999 TL, \%15'i 3000-3999 TL ve \%5'i ise 4000 TL ve üzeri gelire sahiptir.

İstatistiki analiz sonucunda Tablo 2'de belirtildiği gibi kullanıcıların demografik özelliklerinin tümü için turizm ve rekreasyonel amaçlı yapılan aktiviteler arasındaki fark anlamlı bulunmuştur $(\mathrm{p}=0,006-0,005-0,002$ $0,010<0,050)$.

Tablo 2. Demografik özellikler ile turizm ve rekreasyonel amaçlı yapılan aktiviteler arasındaki ilişki

\begin{tabular}{|c|c|c|c|c|c|c|c|}
\hline & & $\begin{array}{l}\text { Tarihi ve } \\
\text { kültürel } \\
\text { mekanları } \\
\text { gezme }\end{array}$ & $\begin{array}{l}\text { Sportif } \\
\text { Etkinlik }\end{array}$ & $\begin{array}{l}\text { Doğal } \\
\text { alanlarda } \\
\text { vakit geçirme }\end{array}$ & $\begin{array}{l}\text { Kent içi ve } \\
\text { Yakın } \\
\text { çevresinde vakit } \\
\text { geçirme }\end{array}$ & Hepsi & $\mathbf{p}$ \\
\hline \multirow{3}{*}{ Cinsiyet } & Kadın & $31(\% 12,7)$ & $85(\% 34,7)$ & $87(\% 35,5)$ & $39(\% 15,9)$ & $3(\% 1,2)$ & \multirow{3}{*}{0,006} \\
\hline & Erkek & $51(\% 17,1)$ & $71(\% 23,8)$ & $102(\% 34,2)$ & $59(\% 19,8)$ & $15(\% 5,0)$ & \\
\hline & Toplam & $82(\% 15,1)$ & $156(\% 28,7)$ & $189(\% 34,8)$ & $98(\% 18,0)$ & $18(\% 3,3)$ & \\
\hline \multirow{6}{*}{ Yaş } & $18-24$ & $9(\% 10,5)$ & $36(\% 41,9)$ & $18(\% 20,9)$ & $18(\% 20,9)$ & $5(\% 5,8)$ & \multirow{6}{*}{0,005} \\
\hline & $25-34$ & $27(\% 16,6)$ & $54(\% 33,1)$ & $58(\% 35,6)$ & $20(\% 12,3)$ & $4(\% 2,5)$ & \\
\hline & $35-44$ & $25(\% 17,4)$ & $41(\% 28,5)$ & $48(\% 33,3)$ & $28(\% 19,4)$ & $2(\% 1,4)$ & \\
\hline & $45-54$ & $13(\% 12,7)$ & $18(\% 17,6)$ & $44(\% 43,1)$ & $23(\% 22,5)$ & $4(\% 3,9)$ & \\
\hline & $55+$ & $8(\% 16,7)$ & $7(\% 14,6)$ & $21(\% 43,8)$ & $9(\% 18,8)$ & $3(\% 6,3)$ & \\
\hline & Toplam & $82(\% 15,1)$ & $156(\% 28,7)$ & $189(\% 34,8)$ & $98(\% 18,0)$ & $18(\% 3,3)$ & \\
\hline \multirow{8}{*}{$\begin{array}{l}\text { Eğitim } \\
\text { Durumu }\end{array}$} & Okur Yazar & $7(\% 9,5)$ & $12(\% 16,2)$ & $33(\% 44,6)$ & $19(\% 25,7)$ & $3(\% 4,1)$ & \multirow{8}{*}{0,002} \\
\hline & İlköğretim & $11(\% 13,4)$ & $18(\% 22,0)$ & $39(\% 47,6)$ & $12(\% 14,6)$ & $2(\% 2,4)$ & \\
\hline & Lise & $19(\% 15,1)$ & $33(\% 26,2)$ & $42(\% 33,3)$ & $28(\% 22,2)$ & $4(\% 3,2)$ & \\
\hline & Önlisans & $4(\% 10,8)$ & $14(\% 37,8)$ & $5(\% 13,5)$ & $11(\% 29,7)$ & $3(\% 8,1)$ & \\
\hline & Lisans & $30(\% 17,6)$ & $57(\% 33,5)$ & $57(\% 33,5)$ & $20(\% 11,8)$ & $6(\% 3,5)$ & \\
\hline & $\begin{array}{l}\text { Yük. } \\
\text { Lisans }\end{array}$ & $9(\% 19,1)$ & $20(\% 42,6)$ & $13(\% 27,7)$ & $5(\% 10,6)$ & $0(\% 0,0)$ & \\
\hline & Doktora & $2(\% 28,6)$ & $2(\% 28,6)$ & $0(\% 0,0)$ & $3(\% 42,9)$ & $0(\% 0,0)$ & \\
\hline & Toplam & $82(\% 15,1)$ & $156(\% 28,7)$ & $189(\% 34,8)$ & $98(\% 18,0)$ & $18(\% 3,3)$ & \\
\hline \multirow{5}{*}{$\begin{array}{l}\text { Gelir } \\
\text { Durumu }\end{array}$} & $\begin{array}{l}\text { Asgari } \\
\text { Ücret }\end{array}$ & $17(\% 13,2)$ & $32(\% 24,8)$ & $47(\% 36,4)$ & $32(\% 24,8)$ & $1(\% 0,8)$ & \multirow{5}{*}{0,010} \\
\hline & $\begin{array}{l}\text { 1000-1999 } \\
\text { TL }\end{array}$ & $19(\% 11,7)$ & $49(\% 30,2)$ & $52(\% 32,1)$ & $31(\% 19,1)$ & $11(\% 6,8)$ & \\
\hline & $\begin{array}{l}2000-2999 \\
\text { TL }\end{array}$ & $32(\% 21,3)$ & $40(\% 26,7)$ & $55(\% 36,7)$ & $19(\% 12,7)$ & $4(\% 2,7)$ & \\
\hline & $\begin{array}{l}3000-3999 \\
\text { TL }\end{array}$ & $8(\% 10,8)$ & $26(\% 35,1)$ & $30(\% 40,5)$ & $8(\% 10,8)$ & $2(\% 2,7)$ & \\
\hline & $\begin{array}{l}4000+ \\
\text { Toplam }\end{array}$ & $\begin{array}{l}6(\% 21,4) \\
82(\% 15,1)\end{array}$ & $\begin{array}{l}9(\% 32,1) \\
156(\% 28,7)\end{array}$ & $\begin{array}{l}5(\% 17,9) \\
189(\% 34,8)\end{array}$ & $\begin{array}{l}8(\% 28,6) \\
98(\% 18,0)\end{array}$ & $\begin{array}{l}0(\% 0,0) \\
18(\% 3,3)\end{array}$ & \\
\hline
\end{tabular}

Cinsiyet açısından bakıldığında hem erkek $(\% 34,2)$ hem de kadın $(\% 35,5)$ kullanıcıların doğal alanlarda vakit geçirmeyi yüksek oranda tercih ettikleri görülmüştür. Yaş açısından 18-24 yaş arasındaki katılımcıların sportif etkinlikleri $(\% 41,9), 25$ yaş ve üzeri tüm yaş gruplarının ise doğal alanlarda vakit geçirmeyi tercih ettikleri belirlenmiştir. Kullanıcıların eğitim ve gelir durumu arttıkça rekreasyonel aktivitelerden sportif etkinliklere katılım tercihi artmıştır.

Kullanıcıların aktivite tercihlerine bakıldığı zaman demografik özelliklerinden yaş ve eğitim durumu ile arasındaki fark anlamlı bulunurken $(\mathrm{p}=0,004-0,000<0,050)$, cinsiyet ve gelir durumu arasındaki fark anlaml bulunmamıştır ( $\mathrm{p}=0,762-0,134>0,050)$ (Tablo 3$)$. 
Tablo 3. Demografik özelliklerle aktivite tercihleri arasındaki ilişki

\begin{tabular}{|c|c|c|c|c|c|c|c|}
\hline & & $\begin{array}{l}\text { Yakın ve } \\
\text { Ulaşılabilir } \\
\text { olması }\end{array}$ & $\begin{array}{l}\text { Sakin ve } \\
\text { güvenli } \\
\text { olması }\end{array}$ & $\begin{array}{l}\text { Ekonomik } \\
\text { olması }\end{array}$ & $\begin{array}{l}\text { Doğal tarihi ve } \\
\text { kültürel } \\
\text { güzelliklerinin } \\
\text { olması }\end{array}$ & Hepsi & $\mathbf{p}$ \\
\hline \multirow[t]{3}{*}{ Cinsiyet } & Kadın & $92(\% 37,6)$ & $61(\% 24,9)$ & $50(\% 20,4)$ & $33(\% 13,5)$ & $9(\% 3,7)$ & \\
\hline & Erkek & $99(\% 33,2)$ & $84(\% 28,2)$ & $59(\% 19,8)$ & $41(\% 13,8)$ & $15(\% 5,0)$ & 0,762 \\
\hline & Toplam & $191(\% 35,2)$ & $145(\% 26,7)$ & $109(\% 20,1)$ & $74(\% 13,6)$ & $24(\% 4,4)$ & \\
\hline \multirow[t]{6}{*}{ Yaş } & $18-24$ & $43(\% 50,0)$ & $17(\% 19,8)$ & $15(\% 17,4)$ & $5(\% 5,8)$ & $6(\% 7,0)$ & 0,004 \\
\hline & $25-34$ & $64(\% 39,3)$ & $42(\% 25,8)$ & $35(\% 21,5)$ & $17(\% 10,4)$ & $5(\% 3,1)$ & \\
\hline & $35-44$ & $47(\% 32,6)$ & $48(\% 33,3)$ & $27(\% 18,8)$ & $17(\% 11,8)$ & $5(\% 3,5)$ & \\
\hline & $45-54$ & $24(\% 23,5)$ & $27(\% 26,5)$ & $22(\% 21,6)$ & $23(\% 22,5)$ & $6(\% 5,9)$ & \\
\hline & $55+$ & $13(\% 27,1)$ & $11(\% 22,9)$ & $10(\% 20,8)$ & $12(\% 25,0)$ & $2(\% 4,2)$ & \\
\hline & Toplam & $191(\% 35,2)$ & $145(\% 26,7)$ & $109(\% 20,1)$ & $74(\% 13,6)$ & $24(\% 4,4)$ & \\
\hline \multirow{9}{*}{$\begin{array}{l}\text { Eğitim } \\
\text { Durumu }\end{array}$} & Okur & $14(\% 18,9)$ & $25(\% 33,8)$ & $26(\% 35,1)$ & $6(\% 8,1)$ & $3(\% 4,1)$ & 0,000 \\
\hline & Yazar & & & & & & \\
\hline & İlköğretim & $29(\% 35,4)$ & $23(\% 28,0)$ & $19(\% 23,2)$ & $5(\% 6,1)$ & $6(\% 7,3)$ & \\
\hline & Lise & $46(\% 36,5)$ & $28(\% 22,2)$ & $23(\% 18,3)$ & $20(\% 15,9)$ & $9(\% 7,1)$ & \\
\hline & Önlisans & $21(\% 56,8)$ & $5(\% 13,5)$ & $6(\% 16,2)$ & $4(\% 10,8)$ & $1(\% 2,7)$ & \\
\hline & Lisans & $66(\% 28,8)$ & $47(\% 27,6)$ & $24(\% 14,1)$ & $28(\% 16,5)$ & $5(\% 2,9)$ & \\
\hline & $\begin{array}{l}\text { Yük. } \\
\text { Lisans }\end{array}$ & $14(\% 29,8)$ & $16(\% 34,0)$ & $11(\% 23,4)$ & $6(\% 12,8)$ & $0(\% 0,0)$ & \\
\hline & Doktora & $1(\% 14,3)$ & $1(\% 14,3)$ & $0(\% 0,0)$ & $5(\% 71,4)$ & $0(\% 0,0)$ & \\
\hline & Toplam & $191(\% 35,2)$ & $145(\% 26,7)$ & $109(\% 20,1)$ & $74(\% 13,6)$ & $24(\% 4,4)$ & \\
\hline \multirow{7}{*}{$\begin{array}{l}\text { Gelir } \\
\text { Durumu }\end{array}$} & Asgari & $39(\% 30,2)$ & $36(\% 27,9)$ & $35(\% 27,1)$ & $14(\% 10,9)$ & $5(\% 3,9)$ & 0,134 \\
\hline & Ücret & & & & & & \\
\hline & $\begin{array}{l}1000- \\
1999 \mathrm{TL}\end{array}$ & $64(\% 39,5)$ & $49(\% 30,2)$ & $27(\% 16,7)$ & $15(\% 9,3)$ & $7(\% 4,3)$ & \\
\hline & $\begin{array}{l}2000- \\
2999 \mathrm{TL}\end{array}$ & $58(\% 38,7)$ & $31(\% 20,7)$ & $26(\% 17,3)$ & $26(\% 17,3)$ & $9(\% 6,0)$ & \\
\hline & $\begin{array}{l}3000- \\
3999 \mathrm{TL}\end{array}$ & $24(\% 32,4)$ & $19(\% 25,7)$ & $16(\% 21,6)$ & $12(\% 16,2)$ & $3(\% 4,1)$ & \\
\hline & $4000+$ & $6(\% 21,4)$ & $10(\% 35,7)$ & $5(\% 17,9)$ & $7(\% 25,0)$ & $0(\% 0,0)$ & \\
\hline & Toplam & $191(\% 35,2)$ & $145(\% 26,7)$ & $109(\% 20,1)$ & $74(\% 13,6)$ & $24(\% 4,4)$ & \\
\hline
\end{tabular}

Yaş grubu açısından aktivitelerin tercih edilme nedenlerine bakıldığında 18-24 (\%50,0), 25-34 (\%39,3) yaş grupları ile 55+ (\%27,1) yaş grubu yakın ve ulaşılabilir olmasını tercih ederken, 35-44 (\%33,3), 44-54 (\%26,5) yaş grupları sakin ve güvenli olmasını tercih etmektedir. Eğitim durumu okuryazar (\%35,1)olan katılımcıların aktivite tercih etme nedenleri ekonomik olması iken ilköğretim $(\% 35,4)$, lise $(\% 36,5)$, önlisans $(\% 56,8)$ ve lisans $(\% 28,8)$ eğitim düzeyindeki katılımcılar ise yakın ve ulaşılabilir olmasını tercih etmişlerdir. Eğitim durumu yüksek lisans $(\% 34,0)$ olan katılımcılar, sakin ve güvenli oluşunu tercih ederken, doktoralı $(\% 71,4)$ katılımcılar ise doğal tarihi ve kültürel güzelliklerin olmasını tercih etmişlerdir.

Kullanıcıların demografik özelliklerinden eğitim durumu ile aktivitelere katılma sıklığı arasındaki fark anlamlı bulunurken $(\mathrm{p}=0,010<0,050)$, cinsiyet, yaş ve gelir durumu arasındaki fark anlamlı bulunmamıştır $(\mathrm{p}=0,361$ $0,636-0,077>0,050)$ (Tablo 4).

Demografik özelliklerle aktivitelere katılma sıklığı arasındaki ilişki incelendiğinde eğitim durumu okuryazar $(\% 33,8)$ ve ilköğretim $(\% 37,8)$ olan katılımcıların düzensiz aralıklarla aktivitelere katıldıkları, lise $(\% 33,3)$ ve önlisans $(\% 43,2)$ düzeyindeki katılımcıların ayda bir/iki defa katıldıkları belirlenmiştir. Lisans (\%40,6), yüksek lisans $(\% 51,1)$ ve doktora $(\% 42,9)$ seviyesindeki katılımcıların ise haftada bir/iki defa aktivitelere katıldıkları belirtilmiştir. Eğitim durumu arttıkça kullanıcıların aktivitelere katılma sıklığı da artmıştır.

Kullanıcıların demografik özelliklerinden eğitim durumu ve gelir durumu ile faaliyetleri doğrudan ve dolaylı etkileyen çevre sorunları arasındaki fark anlamlı bulunurken ( $\mathrm{p}=0,001-0,011<0,050)$, cinsiyet ve yaş arasındaki fark anlamlı bulunmamıştır ( $\mathrm{p}=0,835-0,733>0,050)$. (Tablo 5). 
Tablo 4. Demografik özelliklerle aktivitelere katılma sıklığı arasındaki ilişki

\begin{tabular}{|c|c|c|c|c|c|c|}
\hline & & Hergün & Haftada bir veya iki & Ayda bir iki & $\begin{array}{l}\text { Düzensiz } \\
\text { aralıklarla }\end{array}$ & $\mathbf{p}$ \\
\hline \multirow[t]{3}{*}{ Cinsiyet } & Kadın & $16(\% 6,5)$ & $78(\% 31,8)$ & $84(\% 34,3)$ & $67(\% 27,3)$ & \\
\hline & Erkek & $23(\% 7,7)$ & $111(\% 37,2)$ & $83(\% 27,9)$ & $81(\% 27,2)$ & 0,361 \\
\hline & Toplam & $39(\% 7,2)$ & $189(\% 34,8)$ & $167(\% 30,8)$ & $148(\% 27,3)$ & \\
\hline \multirow[t]{6}{*}{ Yaş } & $18-24$ & $9(\% 10,5)$ & $33(\% 38,4)$ & $27(\% 31,4)$ & $17(\% 19,8)$ & 0,636 \\
\hline & $25-34$ & $10(\% 6,1)$ & $56(\% 34,4)$ & $47(\% 28,8)$ & $50(\% 30,7)$ & \\
\hline & $35-44$ & $11(\% 7,6)$ & $53(\% 36,8)$ & $44(\% 30,6)$ & $36(\% 25,0)$ & \\
\hline & $45-54$ & $7(\% 6,9)$ & $34(\% 33,3)$ & $35(\% 34,3)$ & $26(\% 25,5)$ & \\
\hline & $55+$ & $2(\% 4,2)$ & $13(\% 27,1)$ & $14(\% 29,2)$ & $19(\% 39,6)$ & \\
\hline & Toplam & $39(\% 7,2)$ & $189(\% 34,8)$ & $167(\% 30,8)$ & $148(\% 27,3)$ & \\
\hline Eğitim & Okur Yazar & $7(\% 9,5)$ & $20(\% 27,0)$ & $22(\% 29,7)$ & $25(\% 33,8)$ & 0,010 \\
\hline \multirow[t]{7}{*}{ Durumu } & İlköğretim & $3(\% 3,7)$ & $27(\% 32,9)$ & $21(\% 25,6)$ & $31(\% 37,8)$ & \\
\hline & Lise & $7(\% 5,6)$ & $38(\% 30,2)$ & $42(\% 33,3)$ & $39(\% 31,0)$ & \\
\hline & Önlisans & $5(\% 13,5)$ & $8(\% 21,6)$ & $16(\% 43,2)$ & $8(\% 21,6)$ & \\
\hline & Lisans & $9(\% 5,3)$ & $69(\% 40,6)$ & $55(\% 32,4)$ & $37(\% 21,8)$ & \\
\hline & Yük. Lisans & $7(\% 14,9)$ & $24(\% 51,1)$ & $9(\% 19,1)$ & $7(\% 14,9)$ & \\
\hline & Doktora & $1(\% 14,3)$ & $3(\% 42,9)$ & $2(\% 28,6)$ & $1(\% 14,3)$ & \\
\hline & Toplam & $39(\% 7,2)$ & $189(\% 34,8)$ & $167(\% 30,8)$ & $148(\% 27,3)$ & \\
\hline Gelir & Asgari Ücret & $9(\% 7,0)$ & $44(\% 34,1)$ & $34(\% 26,4)$ & $42(\% 32,6)$ & 0,077 \\
\hline \multirow[t]{5}{*}{ Durumu } & $1000-1999 \mathrm{TL}$ & $15(\% 9,3)$ & $56(\% 34,6)$ & $51(\% 31,5)$ & $40(\% 24,7)$ & \\
\hline & $2000-2999 \mathrm{TL}$ & $6(\% 4,0)$ & $46(\% 30,7)$ & $49(\% 32,7)$ & $49(\% 32,7)$ & \\
\hline & $3000-3999 \mathrm{TL}$ & $4(\% 5,4)$ & $31(\% 41,9)$ & $25(\% 33,8)$ & $14(\% 18,9)$ & \\
\hline & $4000+$ & $5(\% 17,9)$ & $12(\% 42,9)$ & $8(\% 28,6)$ & $3(\% 10,7)$ & \\
\hline & Toplam & $39(\% 7,2)$ & $189(\% 34,8)$ & $167(\% 30,8)$ & $148(\% 27,3)$ & \\
\hline
\end{tabular}

Tablo 5. Demografik özelliklerle faaliyetleri etkileyen çevre sorunları arasındaki ilişki

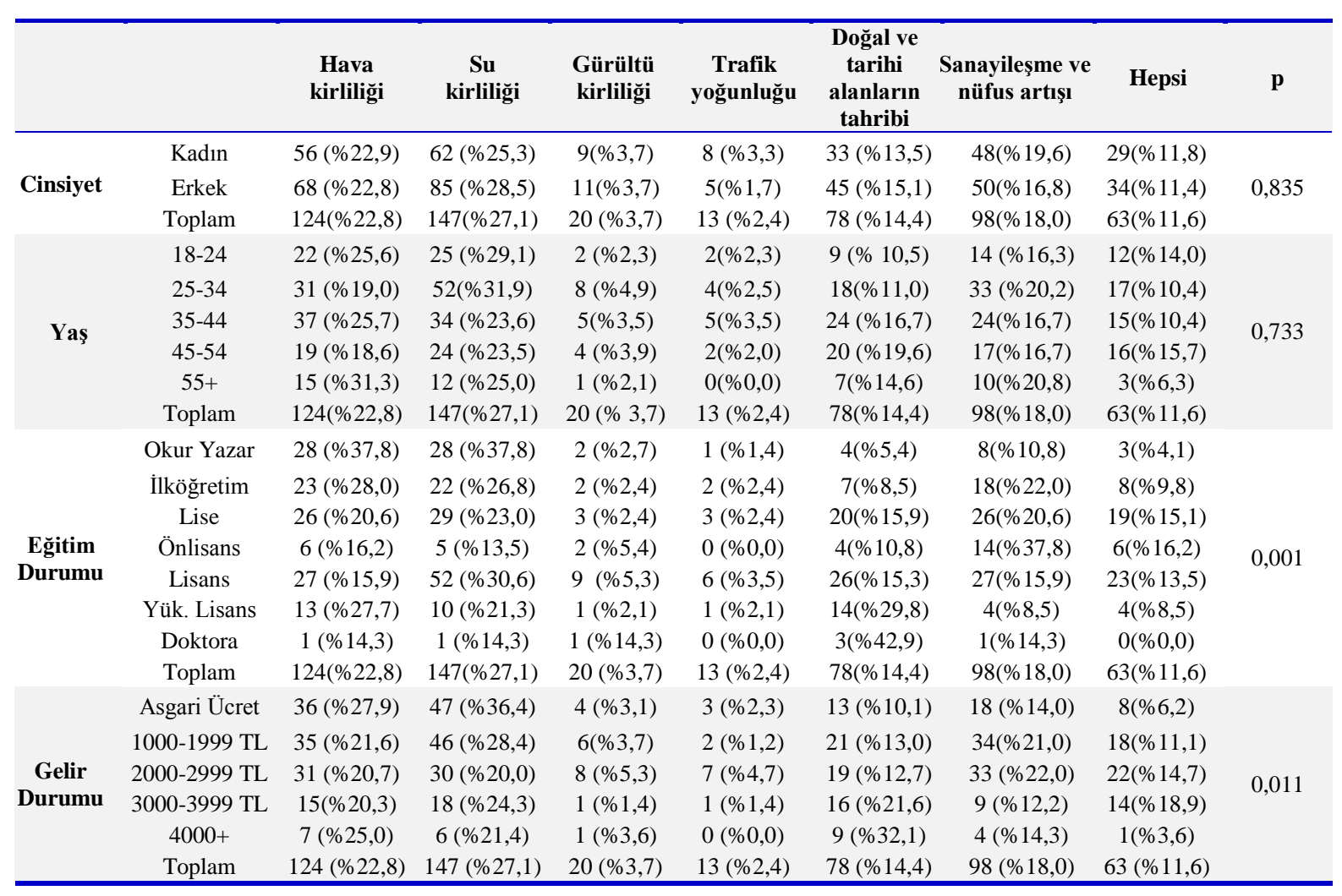

Demografik özelliklere göre faaliyetleri doğrudan ya da dolaylı etkileyen çevre sorunları değerlendirmesinde katılımcılar, gürültü kirliliği ve trafik yoğunluğunu önemli bir sorun olarak görmemişlerdir. Buna karşılık hava kirliliği, su kirliliği doğal ve tarihi alanların tahribi ile sanayileşme ve nüfus artışı katılımcılar tarafından önemli çevre sorunları olarak değerlendirilmiştir. Ayrıca Çevre Mühendisleri Odasının 2017 yılında yapmış olduğu çalışma da Tekirdağ'ın havasının en kirli iller arasında yer aldığını göstermiştir. 


\section{Sonuç}

Çevresel etmenlere bağlı olarak gelişen/şekillenen turizm ve rekreasyonel faaliyetlerin, koruma kullanma dengesi gözetilerek doğru bir şekilde yönetilmesiyle doğal çevre tahribi, görsel kalitenin bozulması gibi insan sağlığını tehdit eden sorunların önlenmesi mümkündür. Bu noktada doğru bir yönetim politikasının belirlenebilmesi için paydaşlardan biri olan kullanıcıların eğilim ve taleplerinin bilinmesi önem taşımaktadır.

$\mathrm{Bu}$ çalışmada Tekirdağ ilindeki kullanıcıların demografik özelliklerinin turizm ve rekreasyonel eğilimlerine etkisi incelenmiştir. Demografik özellikler ile turizm ve rekreasyonel amaçlı yapılan aktiviteler arasındaki ilişki incelendiğinde cinsiyet, yaş, eğitim ve gelir durumuna göre tüm gruplar için doğal alanlarda vakit geçirmek en çok tercih edilen aktivite olurken, ikinci sırada ise sportif etkinlikler yer almaktadır. Bu durum kentleşme ve beraberinde ortaya çıkan sorunların; insanların bu ortamlardan uzaklaşıp doğal alanlarda vakit geçirme ve sağlıklı yaşam için spor yapma isteklerinin artması şeklinde yorumlanabilir. Demirci Orel ve Yavuz (2003)'un Adana'da, Talay ve ark. (2010)'nın Bartın'da, Karaşah (2017)'ın Artvin'de rekreasyonel tercihlere ilişkin yaptıkları çalışmalarda da doğal alanların önemine ilişkin benzer sonuçlar elde edilmiştir. Ayrıca bu çalışma ve yapılan diğer çalışmalarda da kullanıcıların yaşı arttıkça doğal alanlarda vakit geçirme tercihlerinin de arttığı görülmüştür.

Kullanıcılar turizm ve rekreasyon alanlarına yakınlığı ve rahat ulaşılabilir olmasını öncelikli tercih ederken ikinci önem verdikleri kriter ise mekanların sakin ve güvenli olmasıdır. Yakınlık parametresine bağlı olarak aktivite sıklığının artması Demircan ve ark. (2018)'nın yaptı̆̆ çalışmada da belirtilmiştir. Aynı zamanda aktivite sıklığı eğitim seviyesinin artışı ile de doğru orantılı olarak artmaktadır.

$\mathrm{Bu}$ aktivitelere çevre sorunlarının etkisi incelendiğinde ilk sırada su kirliliğinin, ikinci sırada ise hava kirliliğinin olduğu belirlenmiştir. Bu kirlilik unsurları doğal ve tarihi alanların tahribinde etken olmakla birlikte; anket sonuçlarına da yansımış ve özellikle eğitim seviyesi yüksek kullanıcılarda bu durumun farkındalık yarattığı görülmüş̧ür.

Demografik yapı unsurları olan cinsiyet, yaş, eğitim ve gelir durumundan turizm ve rekreasyonel aktivitelerin belirlenmesi, tercih nedeni, aktivitelere katılım siklığ 1 ve aktiviteleri etkileyen çevre sorunlarının belirlenmesinde cinsiyetin etkisinin en az, eğitim durumunun ise en çok olduğu sonucuna varılmıştır. Yapılan bu çalışma ile turizm ve rekreasyonel aktivitelerin demografik yapıyla ilişkili olduğu görülmüştür. Bu aktivitelerin belirlenmesi ve sürekliliğinin sağlanabilmesi için kullanıcıların özellikle yaş grupları, gelir ve eğitim durumlarının dikkate alınması önem taşımaktadır. Bununla birlikte turizm ve rekreasyonel faaliyetlere olanak tanıyan mekanların korunması ve sürdürülebilirliğini sağlamak için yapılan anket çalışmasından yola çıkılarak bazı öneriler geliştirilmiştir:

- Günümüz kentlerinde yaşanan doğal alan tahribi gelecek nesillere sağlıksız bir yaşam ortamı bırakılacağının kanıtıdır. Bu nedenle kentlerin sahip olduğu doğal alanların korunması ve geliştirilmesine yönelik toplumun tüm kesiminde farkındalık oluşturulmalıdır.

- Özellikle kent içi sportif etkinliklere olanak tanıyacak alanların oluşturulmasına önem verilmelidir.

- Rekreasyonel alanların konutlardan belirli hizmet etki alanları içerisinde planlanması, ulaşımın rahatlıkla sağlanmasını kolaylaştırır. Bu nedenle imar planlarında gerekli revizeler yapılmalı ve uygulanmalıdır.

- Sahip olunan kaynakların sürdürülebilirliği için alan kullanım planlaması yapılmalıdır.

- Su kaynakları ve çevresinde kirlenmeye yol açacak tarımsal faaliyetler, sanayileşme, yoğun yapılaşma ve buna bağlı atıkların kaynaklara karışması önlenmeli, kaynağın fonksiyonuna bağlı olmaksızın koruma zonu oluşturulmalıdır.

- Isınma sistemleri için hava kirliliğine olumsuz etkisi olmayan temiz enerji kaynaklarının (rüzgar, güneş, biyokütle enetjisi vb.) kullanımı teşvik edilmelidir.

- Günümüzde taşıt sahibi olma oranı sürekli artmaktadır. Bu da kentsel alanlarda hava kirliliğinin artışına yol açar. Bu etkinin minimize edilebilmesi için toplu taşıma özendirilmeli, çevre dostu ulaşım planlamasi yapılmalidir.

\section{Teşekkür}

$\mathrm{Bu}$ çalışma, Tekirdağ Namık Kemal Üniversitesi, Bilimsel Araştırma Projeleri Koordinatörlüğü’nün NKUBAP00.18.AR.14.05 Nolu projesi tarafindan desteklenmiş̧ir. 


\section{Kaynaklar}

1. Anonim (2017). Hava Kirliliği Raporu, TMMOB Çevre Mühendisleri Odası Yayını. http://cmo.org.tr/resimler/ekler/2145efce8f89f52_ek.pdf Erişim Tarihi: 24.05.2018.

2. Çabuk, A. (1996). Turizm-Çevre İlişkisi: Gündem 21 Kapsamında Turizmde Çevre Bilinci Kazandırılması Üzerine Bir Araştırma. Yüksek Lisans Tezi, Ankara Üniversitesi, Ankara, Türkiye, 96 s.

3. Davras Manap, G. (2016). Göller Bölgesindeki Yerel Halkın Sosyo-Demografik Özelliklerinin Turizm Alışkanlıkları Üzerindeki Etkisi. Mehmet Akif Ersoy Üniversitesi Sosyal Bilimler Enstitüsü Sosyal Bilimler Dergisi. 8(6): 127-148.

4. Demircan, N., Aytatlı, B., Demircioğlu Yıldız, N. (2018). Erzurum Kent İnsanının Rekreasyonel Davranış Biçimleri. Bartın Orman Fakültesi Dergisi. 20(3): 420-430.

5. Demirci Orel, F., Yavuz, M.C. (2003). Rekreasyonel Turizmde Müşteri Potansiyelinin Belirlenmesine Yönelik Bir Pilot Çalışma. Çukurova Üniversitesi Sosyal Bilimler Dergisi, 11: 61-76.

6. Erdoğan, H. (1996). Uluslararası Turizm. Uludă̆ Üniversitesi Yayınları. 531s., Bursa.

7. Karaküçük, S. (1999). Rekreasyon-Boş Zamanları Değerlendirme. Bağırgan Yayınevi, 3. Baskı, 410s., Ankara.

8. Karaşah, B. (2017). Kentsel ve Kırsal Rekreasyon Alanlarına Yönelik Kullanıcı Tercihlerinin Belirlenmesi ‘Artvin Kenti Örneği’. Bartın Orman Fakültesi Dergisi. 19(1): 58-69.

9. Kolcu, H.İ. (1993). Doğal, Tarihi ve Kültürel Açıdan Turizm Potansiyelini Değerlendirme Modeli: Ayvalık Örneği. Yüksek Lisans Tezi, İstanbul Teknik Üniversitesi, İstanbul, Türkiye, 269s.

10. Miran, B. (2002). Temel İstatistik, Ege Üniversitesi Matbaas1, 288s, İzmir.

11. Oğuz, D. (1991). Sinop Sahil Şeridinin Turizm-Rekreasyon Olanaklarının Saptanması Turistik ve Rekreatif Gelişmelerin Çevre ile Etkileşiminin İrdelenmesi. Yüksek Lisans Tezi, Ankara Üniversitesi, Ankara, Türkiye, $170 \mathrm{~s}$.

12. Örücü, Ö.K. (2002). Eğirdir Yöresindeki Mevcut Peyzaj Değerlerinin Turizm Açısından Değerlendirilmesi. Yüksek Lisans Tezi, Süleyman Demirel Üniversitesi, Isparta, Türkiye, 136 s.

13. Sağlık, A., Kelkit, A. (2014). Çanakkale Kent Halkının Rekreasyonel Eğilim ve Taleplerinin Belirlenmesi. ÇOMÜ Ziraat Fakültesi Dergisi. 2(1): 27-36.

14. Sarı, Y. (2001). Amasra İlçesinin Doğal ve Kültürel Peyzaj Değerlerinin Sürdürülebilir Turizm Bağlamında İrdelenmesi. Basılmamış Yüksek Lisans Tezi, Zonguldak Karaelmas Üniversitesi, Zonguldak, Türkiye, $169 \mathrm{~s}$.

15. Talay, İ., Kaya, F., Belkayalı, N. (2010). Sosyo-Ekonomik Yapının Rekreasyonel Eğilim ve Talepler Üzerine Etkisi: Bartın Kenti Örneği. Coğrafi Bilimler Dergisi. 8(2): 147-156. 